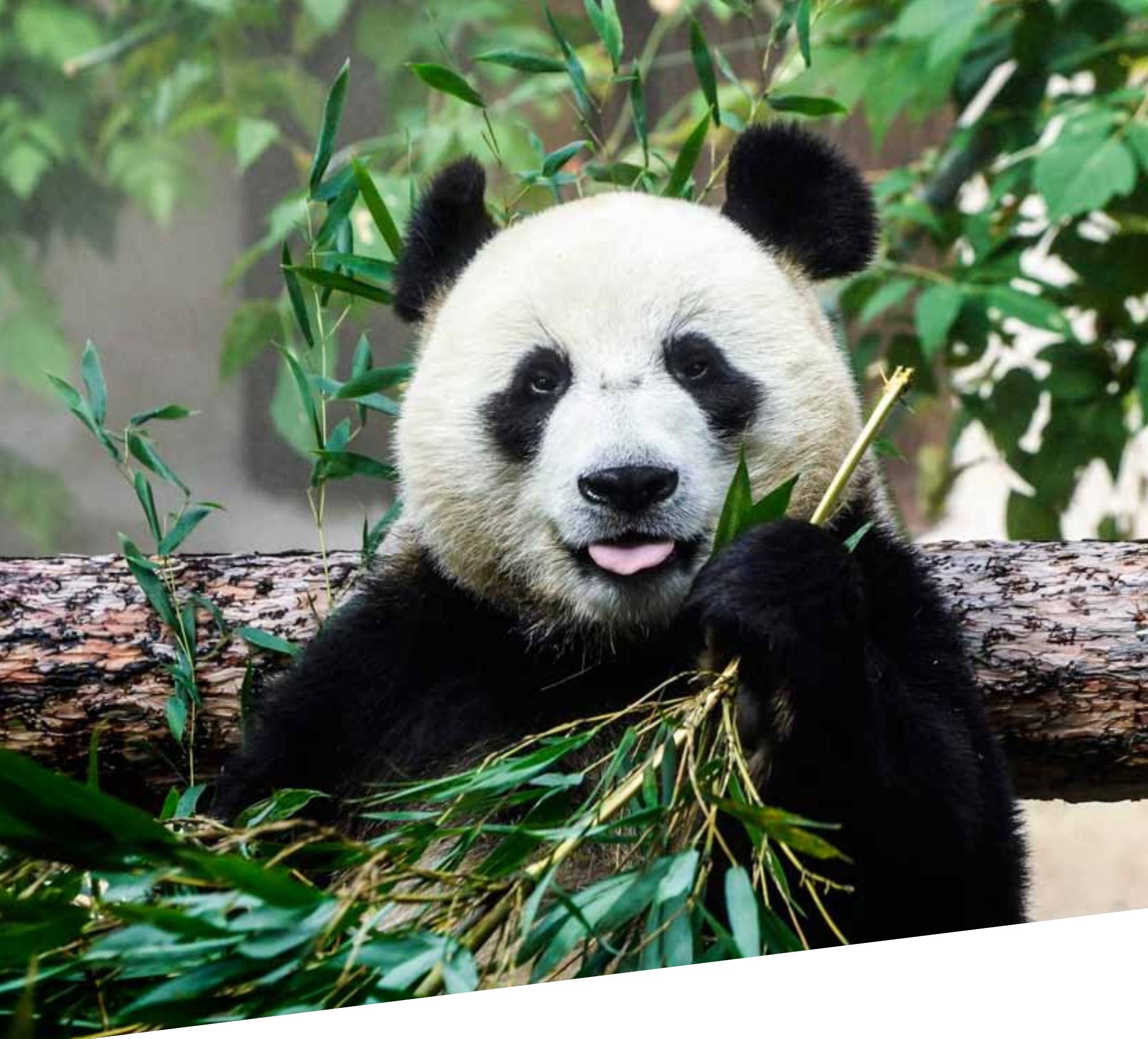

ANALYSIS

\title{
THE TALSINKI TUNNEL
}

CHANNELLing CHINESE INTERESTS INTO THE BALTIC SEA

FRANK JÜRIS

DECEMBER 2019

REDS

EESTI VÄLISPOLIITIKA INSTITUUT 
Title: The Talsinki Tunnel: Channelling Chinese Interests into the Baltic Sea Author(s): Jüris, Frank

Publication date: December 2019

Category: Analysis

Cover page photo: A giant panda (ailuropoda melanoleuca) is pictured at the Moscow zoo in central Moscow early on July 13, 2019. Kirill KUDRYAVTSEV/AFP

Keywords: Talsinki Tunnel, Estonia, Finland, China, security, Belt and Road Initiative, Arctic Silk Road

Disclaimer: The views and opinions contained in this paper are solely those of its author(s) and do not necessarily represent the official policy or position of the International Centre for Defence and Security or any other organisation.

\section{ISSN 2228-2076}

CCInternational Centre for Defence and Security

63/4 Narva Rd., 10152 Tallinn, Estonia

info@icds.ee,www.icds.ee 
infrastructure projects are one day linked with

\section{INTRODUCTION}

On 3 September 2019 at the Party School of the Central Committee of the Communist Party of China (CPC), the party's General Secretary, Xi Jinping, gave a speech titled "Struggle" (douzheng, 斗争), in which he referred to recent history: under Mao, the Chinese people had stood up (zhan qilai, 站起来); under Deng and his successors they became rich (fu qilai, 富 起来); and under Xi's rule, they would become powerful (qiang qilai, 强起来). ${ }^{1}$

Internationally, Xi's assertive foreign policy is best known for the Belt and Road Initiative (BRI), which is expected to increase trade between China and participating countries through infrastructural development. In Northern Europe, China is interested in developing the Polar Silk Road which, using the Northeast Passage route, could significantly cut down the transit time between Asia and Europe. The Tallinn-Helsinki connection should be seen as part of this route, which helps explain why the Chinese investor TouchStone Capital and state-owned construction companies have shown interest in building an undersea rail tunnel between Helsinki and Tallinn (the "Talsinki tunnel").

Furthermore, the Polar Silk Road's entry point to Europe would be a deep-sea port at Kirkenes, Norway, which the Chinese stateowned enterprise (SOE) COSCO has shown interest in developing. ${ }^{2}$ The promoter of the Talsinki tunnel, Finnish businessman Peter Vesterbacka, is also planning to build a rail connection with the help of the Chinese called the Arctic Railway, that would connect Kirkenes with the Finnish railway system by linking it with the city of Rovaniemi. ${ }^{3}$ If all these

\footnotetext{
Wang Zhihui, ““斗争” ! 习近平这篇讲话大有深意” (Xi Jinping speech "Struggle!" carries profound meaning), Xinhuanet, 4 September 2019, http://www.xinhuanet.com/politics/ xxjxs/2019-09/04/c 1124960210.htm (accessed 4 October 2019).

2 Atle Staalesen, "Kirkenes port developers put their faith in the Chinese", The Barents Observer, 7 June 2019, https:// thebarentsobserver.com/en/node/5478 (accessed 4 October 2019).

3 Perttu Ruokangas, “Kiinalaiset saattavat rakentaa Tallinnan tunnelin lisäksi Jäämeren radan - rahoitusta toivotaan etenkin Norjasta" (Besides building the Tallinn tunnel, the Chinese may also construct the Arctic Railway - funding is expected from Norway in particular), YLE, 9 July 2019, https://yle.fi/uutiset/3-10868641 (accessed 4 October 2019).
} the European connectivity project Rail Baltic, China's Polar Silk Road could stretch from the Arctic as far as Warsaw and Berlin.

China's Polar Silk Road could stretch from the Arctic as far as Warsaw and Berlin

This paper will look at the Talsinki tunnel project from a broad strategic perspective related to China's assertive foreign policy in the framework of the BRI. The first section gives an overview of the project, the BRI and existing links between Estonia, Finland and China. The second section analyses Chinese strategic interests through the BRI initiative in general and the Polar Silk Road in particular. In section three, the focus is on the motives of the host countries of the planned tunnel project and asks how well they resonate with Chinese interests in the region. The fourth section looks at the preparations made for the implementation of the project, and the fifth describes the Chinese state actors involved in the project. The final, largest section analyses the security risks involved in the implementation of the tunnel project. In conclusion, it is highlighted that the project entails a number of potential security risks that need to be taken into consideration in its further evaluation by the host countries.

\section{THE TALSINKI TUNNEL AND THE BRI}

The idea of connecting the capitals of Estonia and Finland via an undersea tunnel has been discussed on several occasions since the 1990s. There are currently two competing projects. The first is the official Estonian-Finnish joint preliminary study, the Finest Link Project, which estimates the cost of the rail tunnel to be 13-20 billion euros and the realisation of the project to last from 2025 to $2040 . .^{4} \mathrm{~A}$ feasibility study was conducted in 2016-18 at a cost of $1.3 \mathrm{~m}$ euros, with co-funding from the EU's Interreg Central Baltic programme and

\footnotetext{
4 "FinEst Link Project results: Helsinki-Tallinn railway tunnel to become an engine of regional growth", FinEst Link News, 7 February 2018, http://www.finestlink.fi/en/2018/02/07/ helsinki-tallinn-railway-tunnel-engine-regional-growth/ (accessed 3 July 2019).
} 
involving central and local government bodies from both countries. ${ }^{5}$

Second, there is the project involving a Finnish private company, FinEst Bay Area Development, which is interested in using Chinese expertise and financial assistance to build what would be the longest underwater tunnel in the world (total length $103 \mathrm{~km}$ ). The proposed plans consist of a tunnel connecting the capitals of the two countries and an Arctic Railway connecting the Norwegian port of Kirkenes with Finnish city Rovaniemi in the framework of the BRI. The total cost of the tunnel project would be 15-20 bn euros and in the most optimistic scenario it could be finished by $2024 .^{6}$ This paper focuses on this project.

Chinese infrastructure investments abroad gained prominence in September 2013 when, during a state visit to Kazakhstan, Chinese leader Xi Jinping announced the Belt and Road Initiative. ${ }^{7}$ The BRI is marketed as the new "Silk Road", comprising an "economic belt" connecting Asia with Europe through overland trade routes and maritime "roads" connecting Chinese ports with South-East Asian, Middle Eastern, African and European ones. Almost 70 countries, together accounting for $40 \%$ of global GDP, have joined the BRI. ${ }^{8}$

Estonia joined the BRI in 2017 by signing the Silk Road Initiative Memorandum with the aim of attracting Chinese investment and linking Rail Baltic with the East-West transport corridor. ${ }^{9}$ Lithuania also signed up at the same CEEC-China $16+1$ summit (CEEC $=$ Central and

\footnotetext{
Interreg is the EU's instrument for improving cross-border cooperation through project funding to tackle common challenges in health, the environment, research, education, transport and sustainable energy. Interreg, https://interreg. eu/about-interreg/ (accessed 23 October 2019); “FinEst Link Project", FinEst Link project website, http://www.finestlink.fi/ en/finest-link-project/ (accessed 4 October 2019).

6 Tarmo Virki, “Helsinki-Tallinn tunnel to get $\$ 16.8 \mathrm{bln}$ [sic] from Touchstone", Reuters, 8 March 2019, https://www. reuters.com/article/finland-tunnel/helsinki-tallinn-tunnel-toget-16-8-bln-from-touchstone-idUSL5N20U7PN (accessed 3 July 2019).

7 Philippe Le Corre, "Kazakhs Wary of Chinese Embrace as BRI Gathers Steam”, Carnegie Endowment for International Peace, 28 February 2019, https://carnegieendowment. org/2019/02/28/kazakhs-wary-of-chinese-embrace-as-brigathers-steam-pub-78545 (accessed 3 July 2019).

8 "Explained: Belt and Road Initiative", South China Morning Post, 21 February 2019, https://www.scmp.com/week-asia/ explained/article/2187162/explained-belt-and-road-initiative (accessed 3 July 2019).

9 "Urve Palo signed three economic treaties with China", Ministry of Economic Affairs and Communications, 27 November 2017, https://www.mkm.ee/en/news/urve-palosigned-three-economic-treaties-china (accessed 3 July 2019).
}

Eastern European countries) in Hungary. ${ }^{10}$ (Both countries followed Latvia's example, which had joined in 2016. $)^{11}$

Although Finland has not yet singed an MoU with China on the Silk Road, it has nevertheless been successful in using the east-west railway corridor connecting China with Europe. Since May 2019 a Russian company, RZD Logistics, has provided a freight rail service between the Chinese city of Hefei and Vuosaari in Finland every two weeks with a total transit time of 14 days, carrying everything from consumer goods to electronic equipment. ${ }^{12}$ RZD Logistics CEO, Viacheslav Valentik, is also chairman of the board of Euro Rail Trans JSC, which is related to Russia's geopolitical goals in Lithuania. ${ }^{13}$ The first freight trains from Kouvola in Finland to Xian in China travelled in November 2017 and in 2018 there were over 30 trains, departing for China every few weeks. ${ }^{14}$ In 2019 there have been only five trains from Kouvola to Xian, due to a change of operator from Kazakhstan's KTZ Express to the Russian-Kazakh LogBox. ${ }^{15}$ By 2022, the Kouvola terminal should be able to facilitate trains between 740 and 1,100 metres long, thanks to the European Commission approving funding in the framework of TEN-T. ${ }^{16}$

10 "Prime Minister hopeful about larger trade and freight flows between Lithuania and China", My Government, 28 November 2017, https://Irv.lt/en/news/prime-ministerhopeful-about-larger-trade-and-freight-flows-between lithuania-and-china (accessed 4 October 2019).

11 "Kucinskis: Latvia is ready to work with China", BNN, 6 November 2019, https://bnn-news.com/kucinskis-latvia-isready-to-work-with-china-154242 (accessed 4 October 2019).

12 "The transit service of RZD Logistics between China and Finland has become regular", JSC RZD Logistics, https://www. rzdlog.com/press/600/ (accessed 4 October 2019).

13 Marius Laurinavičius, "Lithuanian Railways: Attach from the east", Vilnius Institute for Policy Analysis, 1 July 2019, http:// www.vilniusinstitute.It/ (accessed 4 October 2019).

${ }^{14}$ Vesa Grekula, "Suomen ainoan maantie- ja rautatiekuljetukset yhdistävän terminaalin rakentaminen alkaa - Kouvolassa varaudutaan yli tuhannen työpaikan syntymiseen" (The construction of the first Finnish terminal connecting transport by land roads and railway starts - Kouvola prepares for the creation of over one thousand jobs), YLE, 19 December 2018, https://yle.fi/ uutiset/3-10563490 (accessed 4 October 2019).

15 Mirjam Tahkokorpi,“Kouvolasta on lähtenyt Kiinaan tänä vuonna vasta viisi tavarajunaa - syynä operaattorin vaihtuminen" (This year only five freight trains have left from Kouvola to China - caused by the change of operator), YLE, 20 August 2019, https://yle.fi/uutiset/3-10929562 (accessed 4 October 2019).

16 "Centralising open access intermodal terminal operations for extra-long freight trains in the Kouvola rail-road terminal", INEA https://ec.europa.eu/inea/en/connecting-europefacility/cef-transport/2018-fi-tm-0039-w (accessed 4 October 2019). The TEN-T programme was established in 2006 by the European Commission to support the construction and upgrading of transport infrastructure across the EU. 


\section{CHINESE STRATEGIC INTERESTS}

In the Chinese historical consciousness, there is an open wound from the colonial era. This is why Mao declared after the establishment of the People's Republic of China in 1949 that the Chinese people had stood up against the colonial powers. It is also the reason all Chinese leaders and political thinkers since the late Qing era have been fixated with the rejuvenation of the Chinese nation. In Xi Jinping's eyes, the “Chinese dream" (Zhongguo meng, 中國夢) can be achieved by improving the livelihood, education and environment of the people and modernising the People's Liberation Army (PLA), while staying loyal to the political system and communist ideology.

Instead of introducing political reforms, $X i$ Jinping believes that the CPC needs to be purged of corruption. Since 2012, more than 2.7 million officials have been investigated and over 1.5 million have been found guilty, amongst them Xi's rivals Bo Xilai and Zhou Yongkang. ${ }^{17}$ In foreign policy $X_{i}$ feels the time is ripe for great-power diplomacy (daguo waijiao, 大國外 交), and he has been much more assertive in international affairs than his predecessors.
Chinese interests in the tunnel project should be analysed in the context of China's broader strategic interests. With the BRI China plans to promote cross-border trade with Central Asia, which would increase the development of its backward western regions and, through economic cooperation, limit the spread of terrorism from the Middle East. The BRI also enables the rapid transport of Chinese goods to their final destination in Europe and secures much-needed energy supplies for the Chinese economy. Investment in infrastructure would help China to deal with overcapacity in steel and cement production and maintain jobs in the construction industry. Moreover, by boosting regional trade the Chinese RMB could become the settlement currency for commodity trade in the region and increase the prominence of transactions conducted in RMB globally. ${ }^{19}$ This could potentially also help politically like-minded countries such as Russia escape US-imposed sanctions. ${ }^{20}$ In 2017 the RMB accounted for about $2 \%$ of global foreign exchange turnover and $1.5 \%$ of global payments, which is still relatively low given that China accounted for almost $20 \%$ of global output and over $10 \%$ of global trade. ${ }^{21}$

From a strategic viewpoint, a land-based economic corridor through Central Asia and Russia to Europe would give China an alternative route to transport its goods to European markets and secure energy supplies in the event of a maritime blockade by the US and its allies. ${ }^{22}$ The Polar Silk Road announced by Xi Jinping in January $2018^{23}$ could
In the South China Sea, China's assertive foreign policy manifests itself in territorial claims and the building of artificial islands with airstrips and military facilities with area denial capabilities. ${ }^{18}$ The South China Sea is important to China due to its abundant natural resources, and artificial islands there create a buffer zone against any maritime blockade by the US and its allies.

\footnotetext{
17 Richard McGregor, "Party Man: Xi Jinping's Quest to Dominate China", Foreign Affairs 98(5), September/ October 2019, https://www.foreignaffairs.com/articles/ china/2019-08-14/party-man (accessed 4 October 2019).

18 Anti-Access/Area Denial (A2/AD) capabilities comprise aircraft, ships and ballistic and cruise missiles intended to limit the freedom of movement of an adversary in a specific region. See "China's Anti-Access Area Denial", Missile Defense Advocacy Alliance, https://missiledefenseadvocacy. org/missile-threat-and-proliferation/todays-missile-threat/ china-anti-access-area-denial-coming-soon/\# edn1 (accessed 23 October 2019).
}

\footnotetext{
19 Simon Shen, "How China's 'Belt and Road' Compares to the Marshall Plan", The Diplomat, 6 February 2016, https:// thediplomat.com/2016/02/how-chinas-belt-and-roadcompares-to-the-marshall-plan/ (accessed 4 October 2019).

${ }^{20}$ Kazuhiro Kido, Masayuki Kubota and Yusho Cho, "Rise of the yuan: China-based payment settlements jump 80\%", Nikkei Asian Review, 20 May 2019, https://asia.nikkei.com/ Business/Markets/Rise-of-the-yuan-China-based-paymentsettlements-jump-80 (accessed 4 October 2019).

${ }^{21}$ Callan Windsor and David Halperin, "RMB Internationalisation: Where to Next?", Reserve Bank of Australia, 20 September 2018, https://www.rba.gov.au/ publications/bulletin/2018/sep/rmb-internationalisationwhere-to-next.html\#r6 (accessed 4 October 2019).

22 Hal Brands, "The Too-Good-to-Be-True Way to Fight the Chinese Military", Bloomberg Opinion, 9 July 2019, https:// www.bloomberg.com/opinion/articles/2019-07-09/howto-fight-china-and-russia-on-american-terms (accessed 4 October 2019).

23 "China unveils vision for 'Polar Silk Road' across Arctic", Reuters, 26 January 2018 https://www.reuters.com/article/ us-china-arctic/china-unveils-vision-for-polar-silk-roadacross-arctic-idUSKBN1FF0J8 (accessed 4 October 2019).
} 
serve a similar strategic purpose by providing an alternative route for China in reaching its target markets in Europe and guaranteeing supplies of natural resources from countries in the Arcticwhich, as a politically stable region, is a more reliable source of resources than the turmoilprone Middle East. ${ }^{24}$ In its white paper "China's Arctic Policy", China states its interests in exploiting the natural resources of the Arctic region and improving the supporting infra-structure to operate the Northern Sea Route on a regular basis. China sees possibilities for cooperation with Arctic states in scientific research, logistics, exploration and the exploitation of natural resources and building ice-class vessels. ${ }^{25}$ and its subbranches in China are facing financial difficulties in paying back the debts created by rapid economic expansion and a lack of government support. ${ }^{29}$

Besides bioenergy, Finland sees opportunities for cooperation in the mining sector in Lapland, which has so far been overlooked by Chinese counterparts. On the BRI route, China is interested in natural resources that are in short supply in China and thus hold strategic importance for it: copper, gold, nickel, aluminium, iron, tin and potassium. Among the list of important minerals for China are also rare earth elements and phosphate, which can also be found in Estonia. ${ }^{30}$ For example, last year Finland exported to China copper valued at $21.1 \mathrm{~m}$ euros, iron and steel at $85.6 \mathrm{~m}$ euros, nickel at $195.3 \mathrm{~m}$ euros, aluminium at $4.4 \mathrm{~m}$ euros and fertilisers containing potassium at $42.3 \mathrm{~m}$ euros. ${ }^{31}$

\section{SHARED INTERESTS}

Finland sees opportunities for cooperation with China in the biorefining, bioenergy and biofuels sectors. ${ }^{26}$ In 2016 a Chinese company, Kaidi Sunshine New Energy Group, announced an investment plan for building a biofuel refinery in Kemi with a total price tag of almost one billion euros. ${ }^{27}$ The project was originally planned to be completed by 2019, but has not yet materialised. ${ }^{28}$ The parent company
Estonia is ranked as the eighth-most important BRI country in terms of natural resources. (Top of the list is Russia, followed by Kazakhstan and Kyrgyzstan. $)^{32}$ The Shanghai chamber's FDI country paper lists Estonian natural resources as $231 \mathrm{~m}$ hectares of forest, $4.8 \mathrm{bn}$ tonnes of oil shale, $2 \mathrm{bn}$ tonnes of peat and $2.9 \mathrm{bn}$ tonnes of phosphate ore. ${ }^{33}$

\footnotetext{
${ }^{24}$ Timo Koivurova, Liisa Kauppila, Sanna Kopra, Marc Lanteigne, Shi Mingming, Malgorzata (Gosia) Smieszek and Adam Stepien, in co-operation with Juha Käpylä, Harri Mikkola, Egill pór Níelsson and Matti Nojonen, China in the Arctic and the Opportunities and Challenges for Chinese-Finnish Arctic Co-operation (Helsinki: Prime Minister's Office, February 2019), p. 25, https://julkaisut.valtioneuvosto.fi/bitstream/ handle/10024/161371/8-2019-China_Arctic andFinland.pdf (accessed 4 October 2019).

25 "China's Arctic Policy", The State Council Information Office of the People's Republic of China, 26 January 2018, http://english.gov.cn/archive/white_paper/2018/01/26/ content 281476026660336.htm (accessed 4 October 2019).

${ }^{26}$ Koivurova et al., op. cit., pp. 65-7.

27 Teija Santaharju, Riikka Rautiainen and Esa Koivuranta, "Kiinalaisyhtiö suunnittelee miljardin biodieseljalostamoa Kemiin - 'Uusi vaihe Suomen teollisessa historiassa" (Chinese company plans a biodiesel factory worth a billion in Kemi - "A new stage in Finnish industrial history"), YLE, 10 February 2016, https://yle.fi/uutiset/3-8661593 (accessed 4 October 2019).

28 Jarno Tiihonen, "Kiinalaisen Kaidin investointipäätös Kemin biovoimalasta tehdään aikaisintaan 2021" (Chinese Kaidi's decision to invest in bioenergy plant will be made at the earliest in 2021), YLE, 23 January 2019, https://yle.fi/ uutiset/3-10603787 (accessed 4 October 2019).
}

Knight Frank, a global property consultancy, has developed a Belt and Road Index (BARI) that comprises six categories: economic potential,

\footnotetext{
${ }_{29}$ Zhang Yuzhe and Leng Cheng, "In Depth: Debt-Ridden Biomass Producer Kaidi Sinks Deeper Into the Mire", Caixing Global, 4 December 2018, https://www.caixinglobal. com/2018-12-04/in-depth-debt-ridden-biomass-producerkaidi-sinks-deeper-into-the-mire-101355364.html (accessed 19 July 2019)

30 Huang Jin, “一一带一路” 沿线重要固体矿产资源分布特征与潜力 分析" (Analysis of the distribution and potential use of solid mineral resources along the "One Belt, One Road" countries), Juguo Xinwen Wang, 29 April 2019, http://news.ggo.net/ html/art/3512529.html (accessed 16 July 2019).

31 “ULJAS - International Trade Statistics", Finnish Customs, http://uljas.tulli.fi/uljas/ (accessed 16 July 2019).

32 Huang, op. cit.

33 “爱沙尼亚，对外投资合作国别（地区）指南”, [Estonia, FDI cooperation country paper] Chamber of International Commerce Shanghai, 2018, http://www.coicsh.com/page. aspx? node $=80 \& i d=543$ (accessed 16 July 2019).
} 
demographic advantage, infrastructure development, institutional effectiveness, market accessibility and resilience to natural disasters. ${ }^{34}$ The BARI evaluates the real-estate market in all the BRI countries; Estonia ranks highest amongst the CEEC and seventh overall, just behind Malaysia (top of the list is Singapore). ${ }^{35}$

\section{PREPARATIONS FOR THE TALSINKI TUNNEL PROJECT}

The Chinese embassy in Estonia has been surprisingly quiet about the huge proposed investment and cooperation opportunity in building the Talsinki tunnel. A rare example of endorsement for the project came in ambassador Li Chao's speech at the delivery ceremony for border surveillance systems to the Estonian Tax and Customs Board by Chinese company

Besides keen interest in natural resources, the Talsinki tunnel project foresees real-estate development on an artificial island, which raises the question of territorial ownership. (The FinEst Bay tunnel project also envisions the construction of an artificial island that could house 50,000 people.) $)^{36}$ In addition, the rapid growth of Chinese investment in the realestate sector could significantly increase the price of housing in the region; this has already happened in, for instance, Canada, where local people found it difficult to purchase private property and provincial governments had to intervene with tax increases for foreign

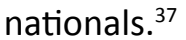

Nuctech on 31 May 2018. ${ }^{38}$ Speaking in Estonia's easternmost city, Narva, ambassador Li acknowledged Estonia's strategic location on the east-west and north-south transport corridors. He pointed out the possibility of connecting Rail Baltic and the Talsinki tunnel with China's Arctic Silk Road initiative in the development of multimodal transport between Europe and Asia. $^{39}$
Estonia is strategically located on the east-

west and north-south transport corridors, says Chinese ambassador
${ }^{34}$ Nicholas Holt (ed.), New Frontiers: Prospects for real estate along the Belt and Road Initiative (Singapore: Knight Frank Research, 2018), pp. 40-1, https://kfcontent.blob.core windows.net/research/1438/documents/en/new-frontiersthe-2018-report-2018-5216.pdf (accessed 4 October 2019).

35 Ibid., pp. 12-14.

36 "Peter Vesterbacka: The Boring Visionary", in Stephan Faris and Matthew Kaminski (eds), "Who to Watch in 2019: The 28 people who are shaping, shaking and stirring Europe", Politico 28, 12 April 2018, https://www.politico.eu/list/ politico-28-class-of-2019-the-ranking/peter-vesterbacka/ (accessed 4 October 2019).

37 Wolf Richter, "Chinese investors are inflating housing markets in the US, Canada, and Australia", Business Insider, 10 June 2018, https://www.businessinsider.com/china-investorsinflating-housing-markets-in-us-canada-australia-2018-6 (accessed 31 October 2019).
At the Estonia-China Infrastructure Forum held in Tallinn in October 2018, the chairman of the China International Constructors Association (CHINCA), Fang Qiuchen, pointed out that there was room for cooperation between Estonia and China in infrastructure, in which China had the necessary expertise and means. Fang said that China was interested in Estonia due to its participation in the Three Seas Initiative, which involves $12 \mathrm{EU}$ members states in the Adriatic,

\footnotetext{
38 The Chinese security and inspection service provider Nuctech is a subsidiary of Tsinghua Tongfang (http://www. thtf.com.cn/en/business/security.html), which is owned by China's top Tsinghua University. The son of former Chinese president Hu Jintao became Communist Party secretary of Tsinghua Holdings in 2008 , before which he was president of Nuctech; he is currently party secretary of Lishui city. "Son of former Chinese president Hu Jintao parachuted into top job in scandal-hit Xian", South China Morning Post, 11 March 2019, https://www.scmp.com/news/china/politics/ article/2189396/son-former-chinese-president-hu-jintaoparachuted-top-job (accessed 6 August 2019).

39 "Opening Remarks by Ambassador Li Chao at the Delivery Ceremony of Nuctech Railway Cargo Inspection Equipment", Embassy of the People's Republic of China in the Republic of Estonia, 6 July 2018, http://ee.china-embassy.org/eng/ dssghd/t1566851.htm (accessed 6 August 2019).
} 
Baltic and Black Sea regions. ${ }^{40}$ The former head of the Economic and Commercial Counsellor's Office in Estonia, Wu Yan, said that Rail Baltic and the Talsinki tunnel projects were linked with the Chinese Polar Silk Road and as such contributed to the development of multimodal transport between Asia and Europe. ${ }^{41}$ discuss the building of the Tallinn - Helsinki tunnel. ${ }^{45}$ In March it was announced that FinEst Bay and TouchStone had signed an MoU for financing the tunnel to the tune of 15 billion euros, of which one-third would be in the form of investment and two-thirds in the form of a loan. ${ }^{46}$

\section{Rail Baltic and Talsinki Tunnel projects are connected with Chinese Polar Silk Road, says Chinese counsellor}

In May FinEst Bay announced the signing of an MoU with Norwegian development company Sør-Varanger Utvikling for building an Arctic Railway connecting Kirkenes with Rovaniemi in Finland, thus linking the Northern Sea
In May 2018 two Finnish entrepreneurs, Peter Vesterbacka and Kustaa Valtonen, founded FinEst Bay Area Development in Finland. ${ }^{42}$ In November 2018 Finest Bay Area Development Estonia OÜ was founded in Estonia for the building of the Tallinn-Helsinki tunnel. ${ }^{43}$ The following month it was announced that FinEst Bay had found its first external investor, ARJ Holding of Dubai, which had promised to invest $100 \mathrm{~m}$ euros in the project. ${ }^{44}$

In January 2019, the heads of China Railway International Group (CICG), Chen Shiping, and Chinese investment fund TouchStone Capital Partners, Kenny Song (Song Qingrong), and Peter Vesterbacka met Estonian prime minister Jüri Ratas and former minister of economic affairs and communications Kadri Simson to
Route with the European railway system. ${ }^{47}$ In July Finest Bay and TouchStone signed an MoU with CICG, China Railway Engineering Corporation (CRECG) and China Communications
Artic Railway connects Northern Sea Route with European railway system

\footnotetext{
40 The Three Seas Initiative is a flexible head-of-state-level political platform to improve the connectivity between 12 member states in the Baltic, Adriatic and Black Sea regions, with special focus on infrastructure, energy and digital connectivity. See Three Seas Initiative Summit, "About," http://three-seas.eu/about/ (accessed 6 August 2019).

41 “2018中国-爱沙尼亚基础设施合作论坛在塔林成功举办” (China-Estonia infrastructure cooperation forum of 2018 was successfully conducted in Tallinn), China International Constructors Association, 23 October 2018 http://www. chinca.org/CICA/info/18102316485711 (accessed 6 August 2019).

42 "Finest Bay Area Development Oy", Yritys- ja yhteisötietojärjestelmä (The Business Information System), (n.d.), https://tietopalvelu.ytj.fi/yritystiedot.aspx?yavain=274 9137\&tarkiste $=430 F 7 B F 2 B 662 A F 312 E 9 D A D 4 E 07 D E 40 A F F 6 C$ DE1E7 (accessed 6 August 2019).

${ }^{43}$ Finest Bay Area Development Estonia OÜ, 30 November 2018, https://www.teatmik.ee/en/personlegal/14618079. Finest-Bay-Area-Development-Estonia-0\%C3\%9C (accessed 7 October 2019).

44 "ARJ Holding to partner on the $€ 15$ billion tunnel", ARJ Holding LLC, https://ariholding.com/arj-holding-to-partneron-the-e15-billion-tunnel/ (accessed 7 October 2019).
}

Construction Company (CCCC) for the final design and construction of the Talsinki tunnel. ${ }^{48}$ (China Railway Engineering Corporation's official English name is China Railway Group Limited

\footnotetext{
45 “陈诗平一行赴芬兰、爱沙尼亚开展商务活动” (Delegation led by Chen Shiping visited Finland and Estonia to develop business relations), China Railway International Group, 10 January 2019, http://www.crecgi.com/?newshow/tp/222/ id/500.html (accessed 7 October 2019); “Peter Vesterbacka, Prime minister of Estonia Juri Ratas Viron, Minister Kadri Simson, CRIG President Chen Shiping and Kenny Song from Touchstone Capital", Finest Bay Area Development, https:// finestbayarea.online/media/65 (accessed 7 October 2019).

46 “中企拟出资170亿美元建世界最长海底铁路隧道: 连接芬兰 爱沙尼亚" (Chinese company plans to invest \$17 billion to construct the world largest underwater railway tunnel connecting Finland and Estonia), TouchStone Capital Group Holdings, http://www.touchstonecapitalpartners.com/page. asp?id=949 (accessed 7 October 2019).

47 "Press release Agreement on Arctic railway planning and implementation", Finest Bay Area Development, 9 May 2019, https://finestbayarea.online/media/82 (accessed 7 October 2019).

48 David Mac Dougall and Petja Pirhonen, "New China deal keeps Tallinn tunnel project on track, but it's still dogged by critics", News Now Finland, 12 July 2019, https:// newsnowfinland.fi/economy-business/new-china-deal-keepstallinn-tunnel-project-on-track-but-its-still-dogged-by-critics (accessed 7 October 2019); "Three Chinese companies to build Tallinn-Helsinki tunnel", Reuters, 12 July 2019, https://www.reuters.com/article/us-finland-estonia-tunnel/ three-chinese-companies-to-build-tallinn-helsinki-tunnelidUSKCN1U70F3 (accessed 7 October 2019).
} 
(CREC), of which CICG is a subsidiary. $)^{49}$ One party to the MoU was a Turkish company, GAMA Holding, with whom TouchStone has created a joint venture ${ }^{50}$ in order to build large-scale industrial and infrastructure projects. ${ }^{51}$ One such project is the construction of the multilevel Istanbul tunnel. ${ }^{52}$

To sum up, China is interested in developing a multimodal transport network between Asia and Europe and the tunnel project would be just one part of the planned transport corridor linking the Northern Sea Route with the European railway system, stretching from northern Norway down to Berlin in the heart of Europe.

\section{CHINESE STATE ACTORS}

The main proposed source of finance for the Talsinki tunnel, TouchStone Capital Partners, does not hide its close connections with Chinese SOEs, but nor does it mention any specific names. TouchStone's website states that of its 30 partners, 15 are SOEs and 15 are insurance and finance companies. ${ }^{53}$ This kind of secrecy goes against the company's publicly declared values of clarity and transparency. ${ }^{54}$ The founder and chairman of the board likes to appear under different names-Kenny Song, Song Fuzai and Song Qingrong (宋青融)which also goes against the company's policy of transparency. ${ }^{55}$

The China International Constructors Association (CHINCA) is a national organisation established in 1988 to promote China's international investments and economic cooperation abroad. Its members have participated in various international projects from transportation, communication and construction to energy and the housing sector. Member companies do not just implement a project, but also provide technical personnel and financial services. ${ }^{56}$ Chinese practice in building infrastructure in Kolasin, Montenegro, is good example: of 2,189 workers on the project, 1,491 (roughly 70\%) are Chinese. ${ }^{57}$ In Serbia, the Sino-Serbian Friendship bridge was built by China Road and Bridge Corporation (CRBC), using about 7,000 Chinese employees. ${ }^{58}$ In the context of building the Tallinn-Helsinki tunnel, this could mean that the 26,000 jobs allegedly created in Finland and Estonia would be filled by Chinese workers. ${ }^{59}$
49 “中国铁路工程集团有限公司” (China Railway Engineering Corporation), Baidu Baike, https://baike.baidu.com/item /\%E4\%B8\%AD\%E5\%9B\%BD\%E9\%93\%81\%E8\%B7\%AF\%E5 \%B7\%A5\%E7\%A8\%8B\%E9\%9B\%86\%E5\%9B\%A2\%E6\%9C \%89\%E9\%99\%90\%E5\%85\%AC\%E5\%8F\%B8/10989000?fr= aladdin (accessed 2 August 2019; "Subsidiaries of CREC", China Railway Group Limited, http://www.crecg.com/ english/2687/3808/3938/index.html (accessed 7 October 2019)

50 "Finestbay [sic] Area Development Lehdistötiedote / Press release, 12.7.2019", Finestbay Area Development, 12 July 2019 (updated 27 July 2019), https://finestbayarea.online/ media/84 (accessed 12 August 2019).

${ }^{51}$ China Investment \& Construction Group (CICG), https://www. cicginternational.com/ (accessed 12 August 2019).

52 "GAMA signed the Memorandum of Understanding with Chinese China Construction Third Engineering Bureau Co., Ltd which is one of the biggest companies in the world to build Three-Level Great Istanbul Tunnel", GAMA Holding A.Ş. 5 August 2019, https://guc.gama.com.tr/en/news/gamasigned-the-memorandum-of-understanding-with-chinesecscec-which-is-one-of-the-biggest-companies-in-the-worldto-build-three-level-great-istanbul-tunnel/ (accessed 12 August 2019)

53 "TCP Group Overview", TouchStone Capital Group Holdings, http://www.touchstonecapitalpartners.com/ newsimg/ 874 20180507143733545.pdf (accessed 12 August 2019)

54 “Our Values", TouchStone Capital Group Holdings, http:// www.touchstonecapitalpartners.com/main.asp?menu id=29 (accessed 7 October 2019).
CHINCA members provide technical personnel and financial services

\footnotetext{
55 Leslie Leino, "Hiinlaste suuri rahapaigutusi saadavad pidevalt segadused, vassimised ja korruptsioon" (Chinese large investments are often accompanied by confusion, dishonesty and corruption), Postimees, 10 March 2019, https://arvamus. postimees.ee/6541706/leslie-leino-hiina-rahapaigutusisaadavad-segadused-vassimised-ja-korruptsioon (accessed 7 October 2019).

56 "About CHINCA", China International Contractors Association, http://www.chinca.org/EN (accessed 7 October 2019).

57 "Chinese building 48 bridge bases in Kolasin", Cafe del Montenegro/Dnevne novine, 13 July 2017, https://www. $\mathrm{cdm}$.me/english/chinese-building-48-bridge-bases-kolasin/ (accessed 7 October 2019).

58 Plamen Tonchev, "China's Road: into the Western Balkans", European Union Institute for Security Studies Brief issue 3/2017, February 2017, https://www.iss.europa.eu/sites/ default/files/EUISSFiles/Brief\%203\%20China\%27s\%20Silk\%20 Road.pdf (accessed 7 October 2019).

59 Aleksi Teivainen, "Major Chinese infrastructure firm to join Helsinki-Tallinn tunnel project", Helsinki Times, 10 July 2019 http://www.helsinkitimes.fi/business/16553-major-chineseinfrastructure-firm-to-join-helsinki-tallinn-tunnel-project. html (accessed 7 October 2019).
} 
have CPC committees in their governing structures, ${ }^{60}$ and CHINCA is no different from the companies it represents. Its chairman, Fang Qiuchen, is also first secretary of the CPC committee in the association. ${ }^{61}$

party committee ${ }^{65}$ and the chairman of CCCC, Liu Qitao, holds the same position. ${ }^{66}$

When talking about China, one has to bear in mind that society's governing structures are still communist, which means that political and economic power is practised at all levels of society primarily by the CPC. The party is mainly concerned with staying in power, which enables it to make decisions that might not be profitable in the short term but

The three SOEs (CREC, CICG and CCCC) that signed the MoU with FinEst Bay for the building of the Talsinki tunnel are members of CHINCA. ${ }^{62}$ All three operate under the supervision of the State Council's State-owned Assets Supervision and Administration Commission (SASAC). ${ }^{63}$ The head of the State Council is premier Li Keqiang, who is also a member of the Politburo Standing Committee, ranked second in the CPC hierarchy only after Xi Jinping. As for CHINCA, the chairmen of the aforementioned SOEs are also the first secretaries of the party committees in the organisations they represent. CREC's former chairman Li Changjin was the first secretary of the party committee in CREC and since August 2019 the new chairman, Zhang Songyan, has the same role. ${ }^{64}$ The chairman of CICG, Chen Shiping, is also the first secretary of the group's

\footnotetext{
60 Zhang Lin, "Chinese Communist Party needs to curtail its presence in private businesses", South China Morning Post 25 November 2018, https://www.scmp.com/economy/china economy/article/2174811/chinese-communist-party-needscurtail-its-presence-private (accessed 7 October 2019); Jude Blanchette, "Against Atrophy: Party Organisations in Private Firms", Made in China, January-March 2019, https:// madeinchinajournal.com/2019/04/18/against-atrophy-party organisations-in-private-firms/ (accessed 7 October 2019).

61 “重温历史 牢记使命一承包商会开展爱国主义教育主题党建活 动" (To review history and remember the mission - CHINCA's Chamber of Commerce organised education on patriotism and party-building event), Sohu, 29 September 2018, https:// www.sohu.com/a/257041108 444154?spm=smpc.content. huyou.9.15595200000232rn2g34 (accessed 7 October 2019).

62 "Key Members", China International Contractors Association, http://www.chinca.org/EN (accessed 7 October 2019).

63 Directory of the State-owned Assets Supervision and Administration Commission of the State Council, http:// en.sasac.gov.cn/n 688 4.htm (accessed 7 October 2019).

${ }^{64}$ China Railway Group Limited, http://www.crecg.com/ english/2687/2720/3853/16861/index.html (accessed 2 August 2019); Gong Hao, “中国中铁选举张宗言为董事长, 聘任陈云为公司总裁” (China Railway Group Limited elected Zhang Songyan to be the chairman of the board, appointed Chen Yun to be the director of the of the company), Phoenix New Media, 25 August 2019, https://news.ifeng.com/ c/7pR2owW21pp (accessed 20 September 2019).
}

become valuable assets in the long run.

\section{SECURITY IMPLICATIONS}

Contrary to claims of profitability, Chinese infrastructure projects abroad have thus far often not lived up to the official slogan of a win-win outcome for both sides. The BRI land belt operator China Railway admitted in August 2019 that on one particular train service to Europe only one of 41 containers was carrying goods. In 2018, with new regulations limiting the number of empty containers to $10 \%$ per train and government subsidies up to $50 \%$ of the cost of shipment, the numbers allegedly improved and last year only $6 \%$ of containers towards Europe and 29\% towards China were empty. ${ }^{67}$

The Finnish Ministry of Transport and Communications found that the proposed Arctic Railway project was not commercially viable and that freight must reach 2.5 million tonnes a year just to cover annual maintenance costs. ${ }^{68}$ The EU's Interreg programme financed the FinEst Link project, which researched the possibility of linking Helsinki with Tallinn via an undersea tunnel. The study found the infrastructure

\footnotetext{
${ }^{65}$ China Railway International Group, http://www.cict.com/ detail/26.shtml (accessed 2 August 2019).

${ }^{66}$ China Communications Construction Company, http://www. ccccltd.cn/aboutus/gltd/ (accessed 2 August 2019).

67 Sidney Leng, "China's belt and road cargo to Europe under scrutiny as operator admits to moving empty containers", South China Morning Post, 20 August 2019, https://www. scmp.com/economy/china-economy/article/3023574/ chinas-belt-and-road-cargo-europe-under-scrutiny-operator (accessed 22 August 2019).

68 "Report on the Arctic railway completed", Finnish Ministry of Transport and Communications, 11 February 2019, https:/ www.lvm.fi/-/report-on-the-arctic-railway-completed-998125 (accessed 7 October 2019).
} 
project to be feasible, if the EU grant covered $40 \%$ of the construction cost and the annual subsidies for operating the tunnel were 280 million euro for 40 years. ${ }^{69}$ The CEO of Estonian ferry company Tallink, Paavo Nõgene, said that with such substantial subsidies the three major ferry companies operating on the HelsinkiTallinn route would be happy to provide their passenger services free of charge. ${ }^{70}$
Defence in the New Era" states that China's overseas interests are a crucial part of the country's national interests and the PLA's job is to protect Chinese people, organisations (zuzhi, 组织) and institutions (jigou, 机构) overseas. To protect China's national interests, it is necessary to build long-distance forces (yuanyang liliang, 远洋力量) and overseas supply points (haiwai bujidian, 海外补给点) supporting power projection abroad. ${ }^{72}$

The American Center for Advanced Defense Studies (C4ADS) researched China's maritime infrastructure

If the BRI is not profitable for China, why does it continue to pursue costly infrastructure projects across the world? First, it should be noted that Chinese SOEs do not have to report back to their investors and constantly please the stakeholders with growth numbers, as public companies in the West do. This enables the SOEs to invest and participate in projects that are not profitable but serve the CPC's longterm strategic goals. Moreover, we should take into consideration the Chinese political system, which-unlike democracies-does not depend on short-term political cycles and consequently enables policymakers to plan ahead for longer periods of time. By October 2019, the CPC had been in power for 70 years.

China's 2015 white paper on Military Strategy states, alongside the importance of safeguarding security and sovereignty, the need to protect China's development interests. The paper argues that, contrary to the former emphasis on land-based threats, the focus should shift to the seas and oceans and to the protection of maritime rights and interests. The paragraph on Force Development in Critical Security Domains says: "protect the security of strategic SLOCs and overseas interests, and participate in international maritime cooperation, so as to provide strategic support for building itself into a maritime power". ${ }^{71}$ The 2019 Defence White Paper “China's National

\footnotetext{
69 "FinEst Link Project results: Helsinki-Tallinn railway tunnel to become an engine of regional growth".

70 "Tallink CEO: For Talsinki tunnel subsidy funds, we could offer free passage", ERR, 23 February 2019, https://news.err. ee/913742/tallink-ceo-for-talsinki-tunnel-subsidy-funds-wecould-offer-free-passage (accessed 7 October 2019).

71 "Full text: China's Military Strategy", Xinhua, 25 June 2015, http://www.chinadaily.com.cn/china/2015-05/26/ content 20820628.htm (accessed 23 August 2019).
} investments in the Indo-Pacific region and found that, contrary to the BRI's official rhetoric of win-win economic development, the investments are seen by Chinese scholars as an opportunity to create political influence and build dual-use infrastructure to support China's long-distance naval operations. ${ }^{73}$ C4ADS refers in its report to the 2015 consensus opinion of 50 scholars from over a dozen prominent Chinese government and university research institutes ${ }^{74}$ which stated that, in order to protect China's core interests (hexin liyi, 核心利益), it was necessary to develop strategic support states (zhanlüe zhidian guojia, 战略支点国家) in the periphery. Goodwill and cooperation can be promoted by offering public goods (gonggong chanpin, 公共产 品) to these strategic support states. ${ }^{75}$
China hopes to generate support by offering public goods
This goodwill is explicit also in Chinese external lending practices, as described in research by Rhodium Group, which reviewed 40 completed renegotiations between 2001 and 2019. These

\footnotetext{
72 "Full Text: China's National Defense in the New Era", Xinhua, 24 July 2019, http://www.xinhuanet.com/english/201907/24/c 138253389.htm (accessed 26 August 2019).

73 Devin Thorne and Ben Spevack, "Harbored Ambitions: How China's Port Investments Are Strategically Reshaping the Indo-Pacific", C4ADS, 17 April 2018, p. 4, https://static1. squarespace.com/static/566ef8b4d8af107232d5358a/t/ 5ad5e20ef950b777a94b55c3/1523966489456/ Harbored+Ambitions.pdf (accessed 8 October 2019).

74 Zhao Weihua, “习近平时代的中国周边外交: 新理念, 新概 念, 新举措” 研讨会综述” (Seminar Summary of the “China Periphery Diplomacy of the Xi Jinping Era: New Ideas, New Concepts, New Measures'), China International Studies 1 (2015), pp. 135-37, cited in Thorne and Spevack, "Harbored Ambitions", p. 20

75 Zhao, op. cit. http://www.ciis.org.cn/gyzz/2015-01/22/ content 7631517.htm (accessed 7 October 2019).
} 
included the following outcomes: 16 writeoffs; 11 deferments, refinancings and term renegotiations; and four denials of additional financing. Although write-offs were the most common result, the amounts were in most cases not substantial. (In the case of Sudan, the forgiven 160 million US dollars represented just $2.5 \%$ of the 6.5 -billion-dollar total debt). ${ }^{76}$

A report by the Center for Strategic and International Studies points out that the process of building infrastructure in another country enables the external actor to influence the political decisions of the host country. For instance, the financing stage provides the lender the opportunity to obtain diplomatic concessions and take operational control of the project. ${ }^{77}$

SOEs. The Chinese company TouchStone Capital signed an MoU with FinEst Bay for the financing of the project. As already mentioned, one-third of the promised 15 billion euros is investment and two-thirds is a loan. ${ }^{80}$ This makes Chinese investors the majority stakeholders and it is more than likely that they will also gain operational control of the project, which can be used as political leverage against the host countries. The BRI slogan of win-win diplomacy in this case means that China wins both times by being the main creditor and the constructor of the project while in addition it gains political leverage by acquiring operational control. The implementation of the project could also lead to technological dependence on China.

It should not be forgotten that China is not a member of the OECD and consequently is not bound by OECD rules on lending, which limit the practice of tied aid credit (the requirement that the money lent is spent on buying goods

In Europe we already have examples of diplomatic favour given to China in the hope of investment or in the case of existing investments. In 2016 Greece, Hungary, Croatia and Slovenia wanted to play down the EU's condemnation of a Permanent Court of Arbitration ruling on China's illegal claim over Philippine territorial waters. ${ }^{78}$ In 2017 Greece vetoed the EU's condemnation of China's human rights violations in the UNHRC. ${ }^{79}$

FinEst Bay's proposed financing plan sees the tunnel being built by Chinese and services from the lender), set minimum interests rates based on the level of country risk (which makes Chinese loans more attractive than those from OECD members) and impose maximum repayment terms (for the lender it is more profitable to generate interest over a longer period than to receive all the money back before the set date). ${ }^{81}$

\footnotetext{
76 Agatha Kratz, Allen Feng and Logan Wright, "New Data on the 'Debt Trap' Question”, Rhodium Group, 29 April 2019, https://rhg.com/research/new-data-on-the-debt-trapquestion/ (accessed 27 August 2019).

77 Jonathan E. Hillman, Influence and Infrastructure: The Strategic Stakes of Foreign Projects (Washington DC: Center for Strategic and International Studies, January 2019), p. 2, https://csis-prod.s3.amazonaws.com/s3fs-public/ publication/190123 Hillman Influenceandlnfrastructure WEB v3.pdf (accessed 8 October 2019).

78 Robin Emmott, "EU's statement on South China Sea reflects divisions", Reuters, 15 July 2016, https://www.reuters.com/ article/us-southchinasea-ruling-eu/eus-statement-on-southchina-sea-reflects-divisions-idUSKCNOZV1TS (accessed 8 October 2019).

79 Tim Nicholas Rühlig, Björn Jerdén, Frans-Paul van der Putten John Seaman, Miguel Otero-Iglesias and Alice Ekman,

"The role of political values in Europe-China relations", in Rühlig et al. (ed.), Political values in Europe-China relations (Stockholm: The Swedish Institute of International Affairs (UI), December 2018), p. 14, https://www.ifri.org/ sites/default/files/atoms/files/full-report-web-version updated 2019.pdf (accessed 8 October 2019).
}

China is not a member of the OECD and consequently is not bound by OECD rules on lending
If a country is unable to repay the debt, the lender can, in the renegotiating process, demand financial concessions, equity in a project, or non-financial concessions. In 2017 Sri Lanka was unable to repay its loans from China for building a new port at Hambantota

\footnotetext{
${ }^{80}$ Anu Jõgi, “Ongi tõsi: hiinlastelt tuleb Tallinna-Helsingi tunnelile 15 miljardit" (True story: Tallinn-Helsinki tunnel will receive 15 billion from the Chinese), Äripäev, 8 March 2019, https://www.aripaev.ee/uudised/2019/03/08/ongitosi-hiinlastelt-tuleb-tallinnahelsingi-tunnelile-15-miljardit (accessed 8 October 2019).

81 Isabella Massa, "Export finance activities by the Chinese government", European Parliament Directorate-General for External Policies of the Union, Directorate B Policy Department Briefing Paper, September 2011, p.10 http://www.europarl.europa.eu/RegData/etudes/note/ join/2011/433862/EXPO-INTA NT(2011)433862 EN.pdf (accessed 8 October 2019); Hillman, Influence and Infrastructure, pp. 5-6.
} 
and in the process of renegotiations in return for writing off a debt of 1.12 billion US dollars it gave China a controlling stake in the port and a 99 -year lease to operate it. ${ }^{82}$ military exercise in the Baltic Sea, which should not have been a surprise because they have been holding joint exercises since 2012. ${ }^{86}$

\section{Inability to pay back debt can lead to}

\section{non-financial concessions}

Besides the risk of falling into a dept trap, all infrastructure has the potential for dual use, which means that commercial infrastructure could be easily used for military purposes.

\section{Commercial infrastructure could be easily} used for military purposes

A clear sign of Chinese interest in playing a bigger role internationally in security matters is the creation of a legal basis for Chinese overseas military operations, put in place through Article 71 of China's 2015 counterterrorism law, which states that, with the approval of the Central Military Commission, the PLA and the People's Armed Police (PAP) can assign people (pai yuan, 派员) on a counterterrorism mission abroad. ${ }^{87}$ In 2016 China reached agreement with Djibouti to build a PLA navy support base and it is believed that in the same year the PLA started joint military patrols The wars in Afghanistan and Iraq are proof of the growing trend of military logistics chains depending more and more on private companies. ${ }^{83}$ Rail Baltic can transport passengers from Tallinn to Warsaw but could just as easily move pre-positioned NATO tanks from Poland to the Baltics.

If this scenario is unrealistic at the moment, it does not eliminate the possibility that in the future Chinese navy vessels will patrol the Northern Sea Route together with Russian forces to protect the Arctic Connect underwater data cable that is planned to connect Europe with Asia via a direct link. ${ }^{84}$ With China's growing influence in the region, it is possible that one day "friendly states" in fear of economic sanctions will be forced to permit the PLA navy to service its ships in the Norwegian deep-water port of Kirkenes in which Chinese shipping company COSCO has shown interest and transport its armoured infantry vehicles via the Arctic Railway and Tallinn-Helsinki tunnel to hold a joint exercise with Russia in Kaliningrad. ${ }^{85}$ In July 2017 the Russian and Chinese navies held a week-long

\footnotetext{
82 Hillman, "Influence and Infrastructure", pp. 8-9.

83 Mark Erbel and Christopher Kinsey, "Think again - supplying war: Reappraising military logistics and its centrality to strategy and war", Journal of Strategic Studies 41(4) (December 2015), pp. 519-44, http://openaccess.city.ac.uk/ id/eprint/15815/1/Think\%20Again\%20\%28AM\%29.pdf (accessed 8 October 2019).

84 "The Arctic Connect Project to Power Business in Northern Finland", Cinia News and Blogs, 23 January 2018, https:// www.cinia.fi/en/archive/the-arctic-connect-project-topower-business-in-northern-finland.html.

85 Staalesen, "Kirkenes port developers put their faith in the Chinese".
} with Afghanistan in the Wakhan Corridor and established a small military base in Tajikistan. ${ }^{88}$

Mathieu Duchâtel, Director of the Asia Programme at Institut Montaigne, believes that following the Djibouti example China is likely to build other naval bases abroad to support its operations in foreign seas, but the problem for Beijing lies in the perception of whether the bases enhance or hinder the international security environment. ${ }^{89}$ Regardless of denials by Chinese and Cambodian officials, there are serious allegations that Cambodia has granted China a 30-year lease on a port near Ream with the right to deploy military personnel and weaponry. ${ }^{90}$

\footnotetext{
${ }^{86}$ Richard Weitz, "Assessing the Sino-Russian Baltic Sea Drill", China Brief 17(12), The Jamestown Foundation, 20 September 2017, https://jamestown.org/program/assessingthe-sino-russian-baltic-sea-drill/ (accessed 8 October 2019).

87 Zhou Wei and Chen Fei, “中华人民共和国反恐怖主义法（全 文) " (Antiterrorism Law of the People's Republic of China (complete text)), Zhongguo junwang, 25 December 2015, http://www.81.cn/jwgz/2015-12/27/content 6832878_8. htm (accessed 17 September 2019).

88 Mathieu Duchâtel, "Overseas Military Operations in Belt and Road Countries: The Normative Constraints and Legal Framework", in Nadège Rolland (ed.), Securing the Belt and Road Initiative: China's Evolving Military Engagement Along the Silk Roads (NBR Special Report \#80) (Seattle and Washington DC: The National Bureau of Asian Research, September 2019), pp. 7-17 [10], https://www.nbr.org/wpcontent/uploads/pdfs/publications/sr80 securing the belt and road sep2019.pdf (accessed 8 October 2019).

89 Ibid., p. 16

90 Timothy R. Heath, "The Ramifications of China's Reported Naval Base in Cambodia", The Rand Blog, 7 August 2019, https://www.rand.org/blog/2019/08/the-ramifications-ofchinas-reported-naval-base-in.html (accessed 8 October 2019).
} 
Chinese professor and former Academy senior fellow at Chatham House, Xue Guifang, acknowledges the importance of security in developing the BRI and believes that in protecting its overseas interests China is more likely to use dual-use support facilities in overseas ports and docks than to build additional naval bases. ${ }^{91}$

China might use a twin-track approach in extending its military presence abroad. It can build naval bases in neighbouring countries with favourable governments like Cambodia, Myanmar, Pakistan and Sri Lanka and opt for dual-use support facilities in countries where governments are more cautious of China's growing influence.

In the EU, Chinese SOEs already have stakes in the following ports: Piraeus (Greece); Bilbao and Valencia (Spain); Marseilles, Nantes, Le Havre and Dunkirk (France); Antwerp and Bruges (Belgium); Rotterdam (the Netherlands); and Marsaxlokk (Malta)..$^{92}$ However, China is facing growing resistance to its infrastructure building projects. In Lysekil, Sweden, a Chinese port-building project that involved CCCC was turned down over environmental and security concerns..$^{93}$ In Greenland, CCCC pulled back from upgrading airports at Nuuk and Ilulissat due to Danish pressure over security concerns. $^{94}$

In 2017 the PLA navy made 290 port visits to all five continents. In the period 2003-18 Chinese naval vessels visited multiple times ports in the following EU member states: the UK, Greece, Germany, Italy, Portugal, Denmark, Finland and Sweden. Naval visits to ports reveal geopolitical, intelligencegathering and cooperation-based priorities. ${ }^{95}$ Even more significant than port visits are joint military exercises and, although the Chinese Ministry of Defence said that the Sino-Russian joint exercise in the Baltic Sea in 2017 was not aimed at any third party, it clearly sent a message of willingness to cooperate with the primary perceived adversary of the Baltic Sea region. According to Beijing-based navy expert Li Jie, it was meant to express Chinese sincerity towards Russia in a region contested between it and the US. ${ }^{96}$
With its Baltic Sea exercise, China added itself to the region's security equation

\footnotetext{
1 Xue Guifang, "The Potential Dual Use of Support Facilities in the Belt and Road Initiative", in Nadège Rolland (ed.), Securing the Belt and Road: China's Evolving Military Engagement Along the Silk Roads, (Seattle and Washington DC: The National Bureau of Asian Research), pp. 47-57 [52], https://www.nbr.org/wp-content/uploads/pdfs/publications/ sr80 securing the belt and road sep2019.pdf.

92 Joanna Kakissis, "Chinese Firms Now Hold Stakes in Over A Dozen European Ports", National Public Radio, 9 October 2018, https://www.npr.org/2018/10/09/642587456/chinesefirms-now-hold-stakes-in-over-a-dozen-european-ports (accessed 8 October 2019).

93 Janne Suokas, "Chinese investors cancel plans for massive deep-water port in Sweden", GBTIMES, 31 January 2018, https://gbtimes.com/chinese-investors-cancel-plans-formassive-deep-water-port-in-sweden (accessed 20 September 2019)

94 Jacob Gronholt-Pedersen and Stella Qiu, "China withdraws bid for Greenland airport projects: Sermitsiaq newspaper", Reuters, 4 June 2019, https://www.reuters.com/article/uschina-silkroad-greenland/china-withdraws-bid-for-greenlandairport-projects-sermitsiaq-newspaper-idUSKCN1T5191 (accessed 19 September 2019).

95 Mathieu Duchâtel and Alexandre Sheldon Duplaix, "Blue China: Navigating the Maritime Silk Road to Europe", ECFR Policy Brief 255, European Council on Foreign Relations, April 2018, pp. 29-30, https://www.ecfr.eu/page/-/blue china navigating the maritime silk road to europeNEWcompressed.pdf.

96 Guo Yuandan, Zhao Yusha, "Advanced PLA navy ship to join joint drill with Russia", The Global Times, 18 June 2017, http://www.globaltimes.cn/content/1052224.shtml (accessed 19 September 2019).

97 Weitz, "Assessing the Sino-Russian Baltic Sea Drill".
}

According to the scenario of the 2017 exercise an undeniable reason to seek a permanent in the region in the form of a support protecting its overseas interests. 


\section{CONCLUSION}

Chinese state actors are interested in developing the Talsinki tunnel project in the framework of the Belt and Road Initiative. The Chinese company TouchStone is interested in providing the finance and the Chinese SOEs CICG, CREC and CCCC are interested in building the tunnel.

Chinese interests in the region are connected with developing the Polar Silk Road that is planned to connect Asia with Europe via the Northern Sea Route, which would, in the event of a conflict with the US, enable China to avoid a maritime blockade. Linking the Northern Sea Route via the port of Kirkenes and the Arctic Railway with the Talsinki tunnel would create an interlocked railway system from the northern coast of Norway to Estonia and, if connected with Rail Baltic, even down to Warsaw and Berlin. China is also interested in having access to the natural resources of the Arctic and Northern Europe, which is a politically stable environment. Northern European countries are interested in increasing trade with China and attracting Chinese investment.
China experts say that, besides boosting trade, the BRI serves the purpose of creating political influence and gaining access to dual-use support ports in the participating countries. China is interested in developing support states to service its navy's vessels abroad, which would enable China to protect its interests and investments in other countries.

With its joint exercise with Russia in the Baltic Sea in 2017, China has already practised the protection of its interests in the area of the proposed tunnel project.

To sum up, the main risks involved in Chinesebuilt strategic infrastructure are: increased Chinese political influence; operational control of the project; technological dependence on Chinese expertise; an inability to pay back loans, which could lead to non-financial concessions; and dual-use infrastructure that could be used for servicing and moving PLA forces. These risks must be taken into account when deciding on future steps regarding the Tallinn-Helsinki tunnel. 


\section{FOLLOW US ON:}

$f$ ICDS.TAllinn, EVI.EESTI

@ @ICDS_TALLINN, @EFPI_EST

in ICDS-TALlinN

INTERNATIONAL CENTRE FOR DEFENCE AND SECURITY ESTONIAN FOREIGN POLICY INSTITUTE 63/4 NARVA RD., 10152 TALLINN, ESTONIA INFO@ICDS.EE, WWW.ICDS.EE, WWW.EFPI.ICDS.EE 